\title{
Exploring Prison Rehabilitation Programs and the Factors That Contributed to Former Prisoners' Career Success
}

Mohd Rizal Bin Mohd Rosli, Mohd Ashraff Mohd Anuar, Siti Rabaah Hamzah

To Link this Article: http://dx.doi.org/10.6007/IJARBSS/v11-i12/11900

DOI:10.6007/IJARBSS/v11-i12/11900

Received: 06 October 2021, Revised: 08 November 2021, Accepted: 30 November 2021

Published Online: 17 December 2021

In-Text Citation: (Rosli et al., 2021)

To Cite this Article: Rosli, M. R. B. M., Anuar, M. A. M., \& Hamzah, S. R. (2021). Exploring Prison Rehabilitation Programs and the Factors That Contributed to Former Prisoners' Career Success. International Journal of Academic Research in Business and Social Sciences, 11(12), 1709-1731.

\section{Copyright: @ 2021 The Author(s)}

Published by Human Resource Management Academic Research Society (www.hrmars.com)

This article is published under the Creative Commons Attribution (CC BY 4.0) license. Anyone may reproduce, distribute, translate and create derivative works of this article (for both commercial and non0-commercial purposes), subject to full attribution to the original publication and authors. The full terms of this license may be seen at: http://creativecommons.org/licences/by/4.0/legalcode

Vol. 11, No. 12, 2021, Pg. $1709-1731$

Full Terms \& Conditions of access and use can be found at http://hrmars.com/index.php/pages/detail/publication-ethics 


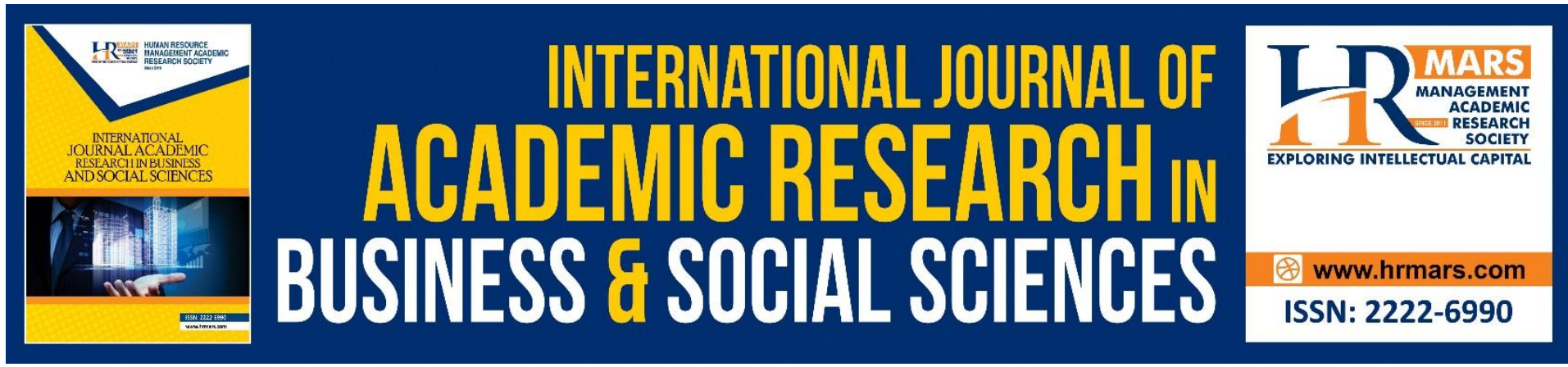

\title{
Exploring Prison Rehabilitation Programs and the Factors That Contributed to Former Prisoners' Career Success
}

\author{
Mohd Rizal Bin Mohd Rosli \\ Human Resource Management Division, Ministry of Communications and Multimedia \\ Malaysia, Malaysia. \\ Email: rizal.rosli@kkmm.gov.my
}

\begin{abstract}
Mohd Ashraff Mohd Anuar
Department of Professional Development and Continuing Education, Faculty of Educational Studies, Universiti Putra Malaysia, Selangor, Malaysia.

Email: mohdashraff@upm.edu.my

Siti Rabaah Hamzah

Department of Professional Development and Continuing Education, Faculty of Educational Studies, Universiti Putra Malaysia, Selangor, Malaysia.

Email: srh@upm.edu.my
\end{abstract}

\begin{abstract}
This study aims to explore the rehabilitation program of prisoners in Prisons and the causes that cause ex-prisoners to be stuck with the phenomenon of homelessness after their release from prison. This study was conducted based on two main research questions, namely: (1) Whether the vocational training program implemented is the main thrust in the approach to treating and rehabilitating prisoners in prisons; (2) What are the factors that contribute towards successful ex-prisoners in their careers. This study was conducted with a qualitative approach in which the data of this study were obtained through in-depth individual interviews from two different individuals and document analysis. The findings of this study show that the rehabilitation program of prisoners in this country is implemented in an orderly and systematic manner under a grand design known as the Human Development Plan (PPI). The PPI conducted in four phases emphasizes the development and strengthening of personality. In the third phase of this program, prisoners are given vocational skills and knowledge in preparation for a career after release. The vocational knowledge and skills imparted are accredited and certified with similar programs conducted outside the prison walls. However, somewhat sadly, after these prisoners were released, they were caught up in the phenomenon of homelessness. Questions about the causes of their involvement can be found in this study. Not only that, but this study also seeks to recommend appropriate actions to prevent the occurrence of similar issues in the future. This study would like to suggest that
\end{abstract}


more in-depth studies related to the formulation of more structured and comprehensive prerelease programs can be made, so that released prisoners are better prepared to face life after release from prison.

Keywords: Vocational Training, Ex-prisoners, Human Development Plan (PPI), Prison, Malaysia Prison Department

\section{Introduction}

The Malaysian Prisons Department (JPM) is the only agency in the country that not only executes sentences but at the same time also plays the function of shaping the personality, discipline, and identity among its inmates. Throughout its 230 -year history, the Malaysian Prison institution has faced various challenges in maintaining prosperity and peace by confining and isolating rioters and problems away from society. At the beginning of its establishment, its orientation was to punish wrongdoing. Now his orientation is to treat and recover. The ethos of the institution is currently actively concentrating all its energies on providing the best treatment and rehabilitation services to its residents through various programs and initiatives that have been planned and arranged in an orderly and systematic manner.

Along with the formation of these human beings, the agency trains practical skills with vocational training and educates its residents with educational opportunities in the field of academia. Zulkifli (2019) emphasizes that the role and function played by this agency is with the commitment that prisoners who have been rehabilitated, treated, and trained with various knowledge and skills can adapt their lives in society after their release later. The culmination of this rehabilitation and treatment initiative was when in February 2002, a form of an integrated program known as the Human Development Program (PPI) was launched. Hasnizam et al (2018) stated that this program is a grand design planned and formed based on an organized and systematic phased system. The programs designed and implemented in this plan cover both physical and spiritual dimensions. The program also emphasizes the formation of discipline and is followed by character formation to rebuild the attitude of identity and confidence among offenders. The UNAFEI (United Nations Asia and Far East Institute for the Prevention of Crime and the Treatment of Offenders) report (2008) states that the PPI is the main program. JPM in its efforts to rehabilitate prisoners. This program is seen as a holistic program because it covers attitude, skills, and knowledge elements.

\section{Problem Statement}

Human Development Program (PPI) has been thoroughly planned and worked on as a grand design in JPM's approach to treating and rehabilitating prisoners. It starts early with various regimental approaches to drop harmful practices and attitudes. Next, slowly the inputs evoke a sense of awareness and sensitivity are nurtured through the modules in the next phase. After passing the initial and second phases, these prisoners are trained with skills to be accessible later, and they can be independent as citizens who repent and are aware of the new spirit. Even in this skill formation phase, the modules from the previous phase continue to strengthen this strength of their soul. This Skills Phase is the main backup for prisoners because the skills and qualifications will guarantee employment opportunities for them.

However, based on the latest developments, this is far from reality. What was hoped for did not come true. The skills and qualifications possessed do not guarantee a career, but post-life 
survival is also not convincing. This can be seen when most ex-prisoners are found homeless, especially in specific locations in Kuala Lumpur. Media reports and several academic studies state that ex-prisoners are stuck with a homeless life. Rosli (2019), in a disclosure through a report exclusively by Berita Harian newspaper dated 27 April 2019, mentioned that almost 90 per cent of the approximately 300 Kajang Prison inmates released every week These exprisoners making some locations around the city of Kuala Lumpur as their homes living homeless, after failing to return to the bosom of their respective families. According to the report, former Kajang Prison inmates who were not picked up or picked up by their family members will head to Chow Kit and Puduraya as temporary locations before they find a better direction after release. The report estimates that only 5-10\% of ex-prisoners are picked up and taken home by their family members. Drani et al. al (2019), in their study, mentioned that the direct effect of being marginalized by family members on ex-prisoners after release is that they are trapped in a homeless life and do not have a job.

Sham and Selvaratnam (2018) noted that ex-prisoners being marginalized by their respective family members resulted in these people losing their place to depend on and shelter in the early moments of post-release life by not having a job. As a result, they had to move away from family members and find friends willing to accept their presence or live as homeless. This homeless life has made the life and survival of these ex-prisoners more difficult and miserable. This difficulty stems from getting a job as a source of livelihood to support life.

Therefore, what training programs are implemented in prisons to treat and rehabilitate inmates? Furthermore, what factors contribute to ex-prisoners being successful in their careers? Therefore, the study needs to be conducted in-depth to explore the questions of this study.

\section{Methodology}

This study aims to explore the implementation of vocational training programs conducted in prisons, which are part of the rehabilitation efforts of prisoners. In addition, this study aims to find out the success factors of a former prisoner in his career.

The qualitative research method has been used to understand a specific phenomenon because it uses a natural approach. This method can dig the real meaning behind a phenomenon without disturbing, teasing, or changing any element in a particular situation. Thus the qualitative research approach is more appropriate in understanding a phenomenon. Therefore, to carry out this study, a qualitative approach was used to look at the factors contributing to a former prisoner's success in a career.

\section{Informant}

The first informant in this study was the Deputy Superintendent of Prisons (TPP), namely Mr A, in Kajang Prison, who acted as the Vocational Training Officer in Kajang Prison and was officially appointed by the management of Kajang Prison as the intermediary officer for this research study. He has extensive experience operating, supervising, and managing vocational training programs at Kajang Prison. 
The second informant for this study is $\mathrm{Mr} \mathrm{B}$. He is a former prisoner who had served a juvenile sentence at Henry Gurney School, Melaka, around 1992. He was 16 years old when he was arrested for robbing a bank in Johor Bharu and convicted of 23 other juvenile criminal charges. The convicted crime was committed around Johor Bharu and extended around the capital Kuala Lumpur. As a teenager, he was involved in vehicle theft, extortion, drug trafficking, human trafficking through foreign prostitutes, and bank robbery. His involvement in these very cunning criminal activities to avoid being sniffed by the authorities led him to the title of 'Toyol King'. Nevertheless, according to him, his imprisonment at the Henry Gurney School had completely changed him, and his conversion had sparked a determination to change.

Once released, he started working in a Japanese electronics factory in Johor Bharu. For his craftsmanship and diligence, he was sent to Japan to undergo training in mechatronics at Matsushita Technical College for three (3) years. Upon returning home in 1999, he was offered a job as a troubleshooting engineer for factories owned by a Japanese company not only in this country but throughout ASEAN. This is because, at that time, there were very few natives or individuals who were skilled in the field and proficient in the Japanese language and culture. The Japanese-owned companies using his fault detection skills are Sumitomo, Sharp, Honda, and Toyota. He is very rich in skills and experience due to his career, which opens up opportunities to travel throughout ASEAN. So in this field, the star shines. Although income in this field reaches more than RM20,000 per month, the call to devotion to his people is very high and deep. The flame for the at-risk and marginalized youths is powerful and profound. He told researchers that this group has not changed like before his life journey. Then he set up his own Tekat Automation College in Kajang, Selangor. The college focuses on vocational vehicle programs for at-risk and marginalized youth and adolescents. The trainees at this College are mostly those involved in juvenile delinquency and are given a second chance to prepare themselves with much-needed vocational training related to vehicles. Records show that 90 per cent of these College trainees got jobs, and some became entrepreneurs by opening their car workshops.

\section{Data Collection}

Due to the COVID-19 pandemic that is spreading around the world, face-to-face interviews are not possible, so the option available is a telephone interview. Some of the questions posed to this informant were answered at length and in detail. The details of the answers illustrate the importance of the vocational training programs that prisoners go through in their rehabilitation process.

\section{Results and Discussion}

This section further discusses the answers to the research questions, namely (1) Vocational training programs implemented are the main thrust in treating and rehabilitating prisoners in prisons; and (2) Factors contributing toward career success ex-prisoners.

Research Question 1: What vocational training programs are implemented to be the main thrust in treating and rehabilitating inmates in prisons?

According to Mr A's informant, the involvement of prisoners in vocational training programs is divided into three types of activities or commonly referred to as workshops. The workshops are Enterprise Workshop, Trust Account Workshop, External Company Cooperation Workshop. The involvement of prisoners in any of the above categories of workshops is 
considered employment. This means that the prisoners involved will be paid appropriate wages based on the type of workshop and work performed. Next, the researcher has summarized all the answers given by the informant, $\mathrm{Mr} A$, as in the following diagram:

\section{Table 2: Verbatim Data Themes from Mr A}

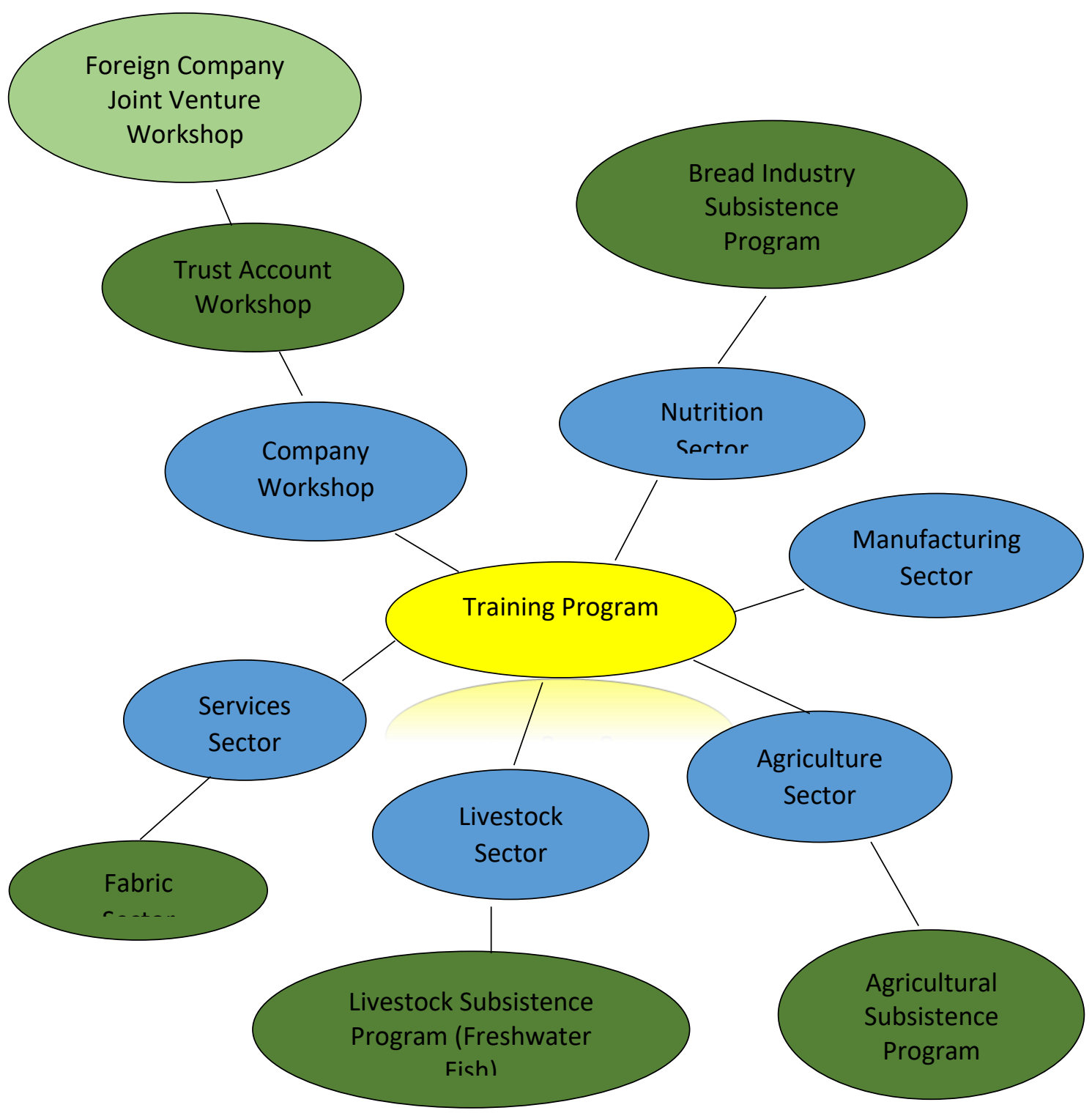

\section{Company Workshop}

This is the starting point for inmates in one skill that they will follow throughout their sentence in prison. The rate of wages for work in this workshop is paid according to the colour of the collar of the prisoner's shirt worn. The colour of this collar symbolizes the level of punishment that a prisoner is going through.

\section{Trust Account Workshop}

The relevant instructors will recommend prisoners who have attended the Enterprise Workshop and have demonstrated significant skill performance to participate in the Trust Account Workshop. This workshop recognizes the specific skills, and the rate of wages paid is 
based on a particular skill level. Therefore, the wage rate is higher than the wage rate in the Enterprise Workshop. The daily wage for the most skilled is RM10, followed by RM7, RM5, and RM3.

\section{Foreign Company Joint Venture Workshop}

Some highly skilled prisoners work in workshops run by outside parties, namely outside companies that operate the manufacture of certain products. These companies enter into joint ventures with JPM by building specific workshops in the area of the Prison complex and supplying specific machines and equipment so that their operations can be carried out inside the Prison. The inmates involved will be trained and supervised by the officers of the respective companies who come daily to the Prison. In time, these companies will leverage the local workforce among prisoners and reduce dependence on foreigners. As a result, the prisoners involved can improve their vocational skills and gain exposure to the operation of high-tech machines. Furthermore, JPM believes that through this joint venture, the companies involved will be able to offer employment opportunities to the prisoners involved after they are released.

\section{JPM Vocational Training Program Accreditation}

Vocational training programs conducted are recognized and accredited through two (2) main types of certification. The certifications are Sijil Kemahiran Malaysia (SKM) certification and Sijil Kecekapan Kemahiran (SKK) certification. A specific organization accredits both forms of certification, and this accreditation is equivalent to a vocational training program accredited by that organization outside the prison walls. Another program is not certified but recognized by JPM as a form of special recognition. It is called the Uncertified Skills Program. This is done specifically for inmates whose basic skills are $3 \mathrm{M}$; that is, reading, writing, and counting are at a very minimal level.

\section{Malaysian Skills Certificate (SKM)}

In principle, the implementation of this vocational training program is in line with the National Technical Education and Vocational Training (TVET) Policy, and the main goal is to create a skilled workforce in Malaysia by 2030 (Star Media Group Berhad, 2019). This means that by providing accredited and recognized vocational training programs, the Ministry of Home Affairs (KDN) has responded to the Government's call through JPM. Therefore, it is essential for JPM that its vocational training program be certified by an accreditation agency so that prisoners who have undergone this program will get a job that is equivalent to their skills and qualifications. In this regard, JPM takes the approach to implement SKM certification and focuses on certification through apprenticeship training methods in the National Dual Training System (SLDN) conducted in industries and skills training institutes (Department of Skills Development, 2017). This SKM certification is managed by JPM and accredited by the Department of Skills Development (JPK), one of the agencies under the Ministry of Human Resources (KSM). There are five (5) levels of certification in this SKM (Department of Skills Development, 2017). For its implementation in institutions managed by JPM, three (3) levels of certification are implemented, namely SKM 1, SKM 2, and SKM 3 (Idris M. D., 2020). The implementation of SKM in JPM institutions is divided into six (6) types of skills sectors, each of which is conducted in specific and separate workshops. The enterprises conducted in these workshops are supervised and supervised by skilled and certified instructors. The teaching staff consists of Vocational Officers cadre in JPM from the Ministry of Youth and Sports (KBS) 
and Prison Officers who have credentials in these skills. They receive a special allowance for vocational skills instructors. The equipment of these workshops also considers the special hardware and equipment required by a particular type of skill. These skills sectors consist of:

\section{Manufacturing Sector}

The sector trains prisoners to manufacture products from raw materials such as wood, iron, rattan, ceramics, and even clay (clay). The work was undertaken in the workshops of this sector, such as iron welding, production of wooden furniture, wood carving, and the manufacture of rattan products.

\section{Nutrition Sector}

Prisoners involved in this sector are trained with skills in the food product industry. The nutritional products cultivated are bread, pastries, snacks, kuih raya and frozen foods. In addition, JPM has also introduced an initiative known as the Industrial Prison Program through this sector. The project under this initiative is known as the Bread Industry Self Sufficiency Program, started in 2013.

\section{Bread Industry Self-Sara Program}

The goal of this initiative is to save on operating costs of institutions under JPM and to further empower prisoners in vocational skills through the use of the latest technology in the bakery industry (National Audit Department of Malaysia, 2013). Through this initiative, JPM produces its bread which is part of the daily menu of prison inmates. The enterprise is made in largescale bakeries in several central prisons, then ship the finished products to several other prisons. The estimated savings is RM50,000 per month for every 2,500 prison inmates (Sinar Harian, 2019). In comparison, if JPM issues a tender for the supply of bread, the cost is RM1.07 million, but with its production, the cost can be saved up to half of the tender cost of RM524,000 (Mynewshub, 2015). This initiative saves the cost of preparing the daily menu and results in reducing the liability of the contractor and improving vocational skills among the prisoners involved.

\section{Agriculture Sector}

Companies run under this sector also apply the Industrial Prison Project initiative, known as the Agricultural Self -Sufficiency Program.

\section{Agricultural Subsistence Program}

The main goal of this program is also to save operating costs of JPM through the production of vegetables that are part of the preparation of daily menus in JPM institutions. Apart from that, it also enables agricultural skills among the prisoners involved. As a result, the savings obtained from this program is more than one-third of the tender cost of RM125,000 compared to the tender cost of RM451,000 (Mynewshub, 2015). The result of this initiative is the strengthening of agricultural skills among the prisoners involved and the reduction of JPM's dependence on contractors.

\section{Livestock Sector}

Prisoners in this sector are given training in ruminant farming (cows, goats, and deer that excrete half-digested food from the stomach into the mouth for re-chewing) and freshwater 
farming. Enterprises run under this sector also apply the Industrial Prison Project initiative, known as the Livestock Subsistence Program.

\section{Livestock Subsistence Program (Freshwater Fish)}

The main goal of this program is also as a cost-saving effort of food preparation, especially freshwater fish, namely catfish, which is part of the daily menu of residents in JPM institutions. The savings from the own production of this catfish is half of the tender cost of RM414,000 compared to the tender cost of RM852,000 (Mynewshub, 2015). The benefit of this initiative to JPM is that the prisoners involved can strengthen their fish farming skills. In addition, on behalf of the Government, JPM can reduce dependence on contractors.

\section{Services Sector}

Through this sector, the prisoners involved are trained in the skills required in service. Among the areas of services trained are hat-making, sewing skills, handling laundry services, cleaning services, landscaping services, and handling grooming services and beauty salons.

\section{Fabric Sector}

This sector trains prisoners in fabric manufacturing so that these skills will be the backbone of prisoners to place themselves in this market that is always in high demand. Among the fabric-making skills trained in this sector are batik making, weaving, and songket. Currently, the products of prisoners in this sector are marketed online in the MyJPM portal, which is an online portal that offers products manufactured by prisoners. In 2016 alone, MyJPM's main sales revenue, namely fabric products, namely Royal Pahang Weaving fabric, Songket Asli Terengganu, batik shirts, women's batik fabrics, and kaftan shirts (MyPride, nd) was RM32 million, compared to the previous year's sales of RM28.8 million (Perak Today, 2016).

Further, according to $\mathrm{Mr} \mathrm{A}$, most of the training or skills programs offered in prisons have skills certificates as follows:

Prisoners who complete the training and pass the assessment will be awarded the CIDB Skills Competency Certificate (SKK), which recognizes them as skilled workers. Among the SKK skill areas followed by the prisoners are brick application skills, plastering skills, tiling skills, carpentry skills, plumbing skills, and concrete work skills, such as Skills Competency Certificate (SKK) Malaysian Construction Industry Development Board - CIDB) is an agency that plays a role in developing human capital in the construction industry. To open up a wide range of employment opportunities to prisoners as required by the industry, CIDB trains prisoners involved in the relevant fields as required. This carefully planned and structured skills training will enable them to gain and improve the skills to embark on a career in the construction industry.

However, there are also uncertified skills programs. Some of these prisoners have never completed primary school or have basic abilities in reading, writing, counting, and speaking fluently in Malay or English. Therefore, their ability is quite limited to follow a certified skills program where the teaching and learning process requires good reading, writing, counting and speaking skills. Nevertheless, this group still has the opportunity to undergo this vocational training program through an uncertified skills program. In this program, the inmates' success is measured by the sales revenue of the products produced through the 
workshops they attend. The enterprise sectors involved in this uncertified skills assessment are similar to the six (6) sectors in SKM; Manufacturing Sector, Nutrition Sector, Services Sector, Agriculture Sector, Agriculture Sector, and Fabric Sector.

In conclusion, this vocational training program clearly shows that the involvement of prisoners in the program is in any sector and type of skill. It also covers the level or type of certification, whether the skills are certified or uncertified. Therefore, all prisoners have the opportunity to follow a vocational training program in preparation for the day ahead in continuing their post-life survival behind the iron curtain through suitable employment opportunities in the future. High confidence has also sparked high inspiration among inmates. For example, in a heavy vehicle handling program, inmates who participate in it have ambitions to become credible express bus drivers. This inspiration came after knowing the career path that attracted the express bus driver from the briefing by the training program operator.

Generally, all the programs implemented in Kajang prison have rehabilitated and treated prisoners very well. These prisoners have become self-reliant, disciplined human beings, have the appropriate religious knowledge and are also skilled in specific fields. This can be seen mainly through the positive effects of the assimilation program held before the release of these prisoners. The SKM and SKK certification in this vocational training program meets the National Occupational Skills Standard, better known by the acronym NOSS (National Occupational Skills Standard). This means that the vocational skills acquired during the sentence in prison are the same standard skills as those given outside the prison. Therefore, ideally, for any ex-prisoner who applies for any form of employment that requires SKM or SKK certification, his chances are on par with other individuals.

The stigma that still exists in society is still challenging to eradicate. Society still finds it difficult to accept the presence of ex-prisoners in daily life. Negative perceptions of ex-prisoners cause their chances of getting a suitable job to be blocked. As a result, some of these ex-prisoners moved to places far from their place of origin to escape the stigma of the local community in starting a new life.

Research question 2: What factors contribute to the success of ex-prisoners in their careers? All the asked questions were analyzed based on the verbatim of the interview. The data obtained were then clustered based on specific themes. The following are the data from the interviews that have been clustered based on specific themes. 


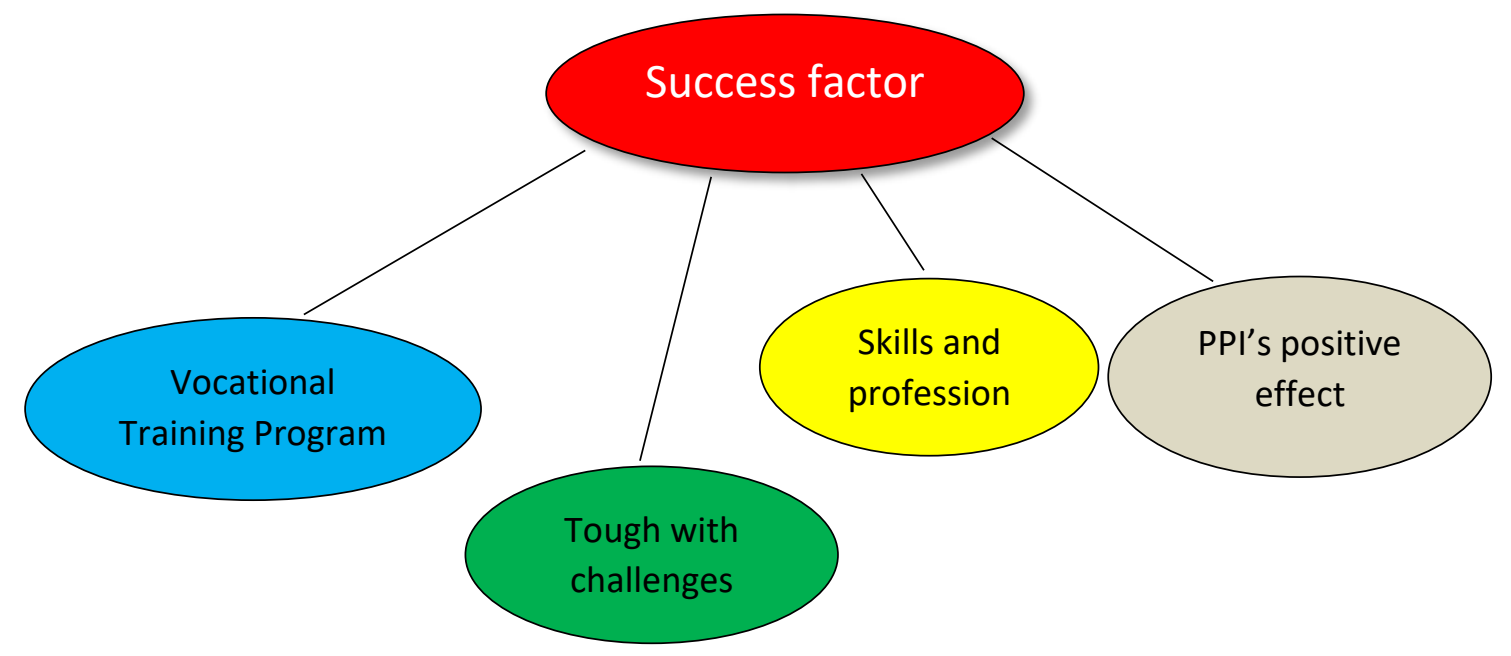

Table 3: Verbatim Data Themes from Mr B

When $\mathrm{Mr} \mathrm{B}$, the second informant, was undergoing vocational training at Henry Gurney School (SHG), the program was referred to as the National Vocational Training Council (MLVK) certification. The objective of implementing this program is clear: to prepare prisoners with specific skills so that after being free, they will be able to work and be independent. At that time, JPM did not yet have its teaching staff as it does now. Instructors for vocational programs at SHG come from various nearby skills institutions; among them is from Pusat Giat MARA Melaka.

In addition, the Government makes vocational programs as a medium of social intervention because most offenders do not have an educational background that can boost their social status in society if only sentenced to prison without any supply of knowledge or skills. In addition, vocational training can also shape a person's personality for the better.

"At that time, I think even now, this skill is seen as a social intervention for detainees. Because, the impression that whoever enters the correctional institution at that time must have a family background that is not ok, an educational background that is not ok, so vocational education is a thing that can shape them" (Hassan, 2020).

While serving a juvenile delinquency sentence at SHG, $\mathrm{Mr} B$ was selected to follow the Welding and Metal Fabrication (KFL) program at Level 1. He mentioned that he was at the KFL workshop almost every day while at SHG. This has sharpened his skills, and at the same time, his confidence in the field is high. In addition to acquiring skills, he is also equipped with soft skills. He said soft skills such as punctuality, team spirit, and being positive are complementary to the set of vocational skills that have been acquired.

He mentioned that he was at the KFL workshop almost every day while at SHG. This has sharpened his skills, and at the same time, his confidence in the field is high. In addition to acquiring skills, he is also equipped with soft skills. He said soft skills such as punctuality, team spirit, and being positive are complementary to the set of vocational skills that have been acquired.

"Soft skills. It is complementary to the craftsmanship skills given ...." 
The researcher found that Mr B was very positive in reacting to this question. He stated that the vocational training program implemented at the Malaysian Prison institution had highlighted two (2) aspects in him, namely building and developing talent and unearthing one's potential to the maximum level. This means that the training program has aroused the tendency and confidence to do something diligently and earnestly and reach the best level. According to him, his potential is more evident in skills than in the academic field. He stressed that skills are a significant supply after tasting released from prison later. In addition, through this vocational training program, the positive elements are the construction of specific skills, extensive knowledge in the field involved, and the right attitude, which immensely helped him when he plunged into the world of work after freedom. He added that throughout his experience of working hard in the world related to this skill, the right and proper attitude is the most expensive asset for a person to succeed in the world related to this skill.

"The benefits in terms of talent building and potential can be highlighted through skills training because I do not incline the academic stream. After all, skills will supply me then when coming out of a correctional institution.

When second year of work in the machining department, I used very little. The training elements of skills, knowledge and attitude help me perform the work. That attitude is the most expensive in the skill stream."

$\mathrm{Mr} \mathrm{B}$ stressed that the skills that have been acquired along with this positive attitude, of course, can open up good job opportunities for these ex-prisoners.

"Because they want to work. They already have the skills. Sewing skills, cooking, waiter, welding, automotive, lots ...."

He also stated that although there is equipment and technology used in this vocational training program, some do not follow the passage of time; even so, the skills acquired in this prison still comply with the basic principles of a particular skill area. This means that these ex-prisoners will have the ability to develop their skills in line with the needs of the industry in the future. This can be seen in various industries such as the manufacture of boxes, the manufacture of packaging materials, the manufacture of wood products, and the manufacture of textiles.

"I have never denied what they got in prison, which correctional institution. Although the technology used in it is outdated, at least the basics are there."

"Industry such as boxes, packaging, wood, is there anything? No problem at all. Especially prison. Because the prison with the stitches is the champion. How Many Sewing Factories Do We Have? Many textile factories."

$\mathrm{Mr} \mathrm{B}$ also stated that a good mastery in the field of steel welding skills succeeded in convincing Malaysian Resources Corporation Berhad (MRCB) to hire prisoners to work as welders in the Light Rail Transit Depot 3 (LRT3) construction project in Johan Setia (Che Noh, 
2020). This is strong evidence that shows how vocational training programs in Malaysian Prisons institutions have shaped the skills needed in the job market. In addition to the skills formed, positive attitudes among ex-prisoners are a significant added value in positioning themselves in the job market. This former prisoner is very disciplined and punctual. This is the excellent attitude formed from PPI. Armed with this high discipline, employers believe they will not face any problems with these ex-prisoners. All employers need to provide some guidance within the scope of their field of work only.

"All these prisoners, the discipline chapter is tiptop. Just want to keep him out. That is why employers, like now Matsushita, Panasonic, this is what he said. We want to take all the prisoners to work with us if possible. Because of discipline. The employer just needs top-up only."

Most of these free ex-prisoners lost their cause and direction because no family members came to pick them up or were marginalized by family members. They have no place to shelter and no resources to get food. Most of them will be heading to Jalan Chow Kitt, Kuala Lumpur. This location has become a prime location for ex-prisoners to seek support and assistance. At this time, most former aid workers are willing to do any kind of work to survive; skills acquired in prison are simply written on the certificate only. If they meet with an honest person, then they are safe. If not, then life is chaotic and if the wrong step, he will be thrown back into prison. The challenge for those invited home by family members or heirs is to deal with family members, neighbours, and the surrounding community who cynically view themselves as ex-prisoners. Every day is spent with various attempts to get a job.

\section{Challenge of No Self-Introduction}

The survival of a former prisoner begins with finding a job. With a job, he will be able to meet his daily needs to continue his life. Often employers are interested in hiring exprisoners because they know that these ex-prisoners are a trained workforce, and the cost of hiring them is relatively cheaper than hiring foreign workers.

"... One day, the cost for a foreign worker can reach up to 130 ringgit. If we hire an outsourcing agent, we are willing to pay 130 ringgit. He outsourced his pay to foreign workers, plus 12 hours of overtime work can be up to 50 ringgit, a thousand and a half a month. Plus, over time, he can share up to 70 ringgit. There are still 60 ringgit a day, one head. This is this business. Accommodation can be for free, isn't it?"

Nevertheless, employers' big hurdle is managing time and energy-consuming administrative issues. The issue began with the absence of identity cards for most exprisoners. Most ex-prisoners face the issue of lack of valid identification. Their identity cards were lost after being handed over to the authorities as soon as they were arrested for imprisonment. Most of them cannot afford to pay the high fines for making new identity cards. This makes efforts to apply for jobs stagnant and drags on to other issues such as failure to open a bank account and even more unfortunate when arrested by the authorities for not having a valid identity card. In the absence of identity cards, bank accounts could not be opened, Employees Provident Fund (EPF) accounts and Social Security Organization (Socso / 
SOCSO) accounts could not be opened. The employer could not afford the cost of the fine and had the time to make a new identity card.

Had these issues not arisen, Mr B said that ex-prisoners could get a job as a production operator with a salary of not less than RM 2,500 a month. This is compounded by the willingness of many employers to provide free accommodation for their employees. This is because employers know that ex-prisoners already have the good attitudes and skills their companies need.

\begin{abstract}
"That's why I have an article I wrote for local workers, factory workers if there is an attitude, what kind of craft is it, easily starting the work of 2,500 production operators-no real problem. However, the opportunity can be used by these ex-prisoners. However, that is it, and the questions are to go check the records of the people, the discrimination against the group of prisoners. These juvenile offenders want to work."
\end{abstract}

Of course, with the skills that have been acquired and the positive attitudes that have been formed, ideally, these ex-prisoners are a much-needed workforce by employers in various industrial sectors. Furthermore, the cost of hiring ex-prisoners as workers is more economical than foreign workers.

\title{
The Challenge of Stigma from Prospective Employers
}

In many cases, most employers still require that the authorities authenticate eligibility certificates in job applications. So this is where the stigma of prospective employers against ex-prisoners begins. Although the JPM only put the statement "Kajang Industrial Vocational Center" (PVI Kajang) in the skills certificates of ex-prisoners, when employers need certificate verification, their identities are exposed. Even if someone is hired, the rate of wages received is not only not commensurate with the skills possessed, but even worse, is not equal to other individuals with the same quality

"That is why when I first went out, the big challenge we faced when the certificate we received was recorded to have been educated at Henry Gurney school, so it was difficult to get a job. (...) That puts a burden on people who want to work. So it is hard to get a job. So, in the end, I stayed by entering the world of work with the lowest employment ever. Moreover, that is also the case until now. So even though he did not write the certificate from anywhere, but for the confirmations of where he studied, he has a challenge there. I can dare to say because many of my boys are ex-prisoners, my brothers and sisters who came out to ask for work help asked for a confirmation letter from the prison."

Status as a former prisoner in the process of furthering his studies at any Government-owned educational institution at any level is not an obstacle. This is because former juvenile prisoners achieved excellent results in school level examinations such as PTK 3 and SPM while in detention. These, when independent, take the initiative to further their 
studies at the Certificate, Diploma, and First Degree levels. Even so, as soon as they graduated and applied for jobs with Government agencies, security censorship had ruined their dreams.

"... When there is a Henry Gurney school student who excels academically, he gets an offer to enter the university, at the same time he gets an offer of a soldier and refuses to go to university and he accepts a soldier, time to report, reject because there is a record. So he lost two. So the boy reported that now there is no way because the police record states that someone, he has a record near Bukit Aman, what is it all about. So, it seems. That thing sometimes should not happen. But, things like nilah that end up being troublesome and wanting to fix it is not an easy process. So, what happened to this boy?"

\section{Challenge Failed to Stand Alone}

Mr B stated based on his experience over the years, out of 10 prisoners released, $9 / 10$ would fail in their quest for a new life. Those who fail are not ordinary prisoners while in prison. These are the icons of success in PPIs and vocational training programs. Only one person will succeed, that is, the one whom he guides after freedom. Even so, with the support available, he could only guide one person. Then, what happened to the others?

"... Out of 10 who came out, that I met, who can guide me only one. Nine will break. It is reality. Nine will collapse. And I can still connect with those nine, but what can I do? And these ten are successful people in prison. Not only receive training, icons...."

Mr B believes that most prisoners are incapable of repeating the good lives and successes enjoyed as in prison. Life in prison is under complete control by prison management, while post-release life is no longer under control. Currently, the situation is worse with the Government's ban on PKP and PKPB during this COVID-19 pandemic. Prisoners who are currently being released, where are they headed? In the absence of public transportation, no family members are invited home or are directly marginalized by family members; where are they headed? Without having any identification, no money, and outside support, they end up living on the streets as vagrants or homeless.

"For example, today, the order to leave, say now PKP is not $B$, what bus does he want to take from Kajang or Simpang Renggam Prison, then where does he want to go? If the family is willing to take another story. He's kind of stubborn; the family doesn't want to, where does he want to go? He wants to get out of prison, he wants to go to the bus stand, the bus doesn't. Lastly, he wandered around where to be caught. Attacked. Takda duit. Enjoy a new three days outdoor life. It's not that it doesn't happen. Bad luck, IC is no more. So those who are lucky to live up to a month, hungry because everyone has done bad things. That thing is too small, actually. But he has an impression." 


\section{Challenges of Stigma in Society}

The findings of this study show that stigma against ex-prisoners occurs among local employers who have small and medium-sized enterprises. The stigma that occurs prevents a former prisoner from getting a job. His chances are also affected due to the reckless attitude of employers who choose foreign workers over local ex-prisoners. If a former prisoner is employed, the position and rate of wages or salary he receives are not equivalent to the qualifications and skills possessed. Such enterprises usually do not adopt specific codes or standards, especially those related to the personal information of a prospective employee. Without adopting such codes or standards, prejudice against ex-prisoners will continue to occur without proper control. This is quite different from employers who run large-sized enterprises and divert their economic activities to the international level. International conglomerates own such enterprises that adopt high human resource codes and standards. Therefore, stigma and prejudice are rare in such companies. For example, electronic companies such as Matsushita Panasonic in Shah Alam, Selangor, adopt the Electronic Industry Code of Conduct (EICC). It is a standard that preserves a worker's rights from the perspective of human rights. Such standards do not discriminate against a person because of his or her background and life history as a former prisoner. The priority is the qualifications and skills he has to meet the set standards.

\section{Application of Social Cognitive Career Theory (TKKS)}

Social cognitive career theory (SCCT) aims to describe three interrelated aspects of career development: (1) how academic foundations and career interests develop, (2) how educational and career choices are made, and (3) how academic and career success is earned. Developed by Robert W. Lent, Steven D. Brown, and Gail Hackett in 1994, SCCT incorporates various concepts (e.g. interests, abilities, values, environmental factors) from previous career development theories, using Albert Bandura's general social cognitive theory as a unifying framework. Three closely related variables - self-efficacy beliefs, outcome expectations, and purpose - serve as the basic foundations of SCCT. Self-efficacy refers to a person's personal beliefs about his or her ability to perform a particular behaviour or action. Unlike global confidence or self-esteem, self-efficacy beliefs are relatively dynamic (i.e., changeable) and specific to a particular domain of activity. In this study, an inmate who had undergone a vocational training program differed in their self-efficacy on required behaviours in different areas of employment. For example, a prisoner may feel very confident in completing tasks that require skills to succeed but feel less confident in his or her abilities in the social field, such as dealing with a prospective employer for a job interview.

In short, former prisoners develop a lasting interest in an activity when they see themselves as competent in carrying it out and expect the activity to produce valued results. On the other hand, interest is unlikely to develop in activities where people doubt their competence and expect negative results.

\section{References}

Malek, A. M. A., Sulaiman, W. S., Subhi, N., \& Ibrahim, F. (2018). Faktor Harapan dan Efikasi Kendiri Sebagai Peramal Terhadap Kebolehsesuaian Kerjaya dalam Kalangan Penghuni Penjara. Malaysia Correctional Journal, 110.

Abdul Jalil, S. J. (2017). Pengaruh program keagamaan dan sokongan sosial terhadap konsep kendiri, kebimbangan dan kemurungan: Kajian dalam kalangan banduan wanita di Malaysia . Akademi Pengajian Islam, Univesiti Malaya. 
Abdullah, H., Rosnon, M. R., Abu Samah, A., Abu Samah, B., Nor, W. M. M., Dahalan, D., \& Harun, S. R. (2018). Profile of Malaysian Inmates. Malaysia Correctional Journal, 98.

Adiputra, S. (2016). Lingkaran Konseling. Retrieved from https://bkpemula.wordpress.com/2016/06/09/social-cognitive-career-theory-scct/

Akers, R. L. (1990). Learning Theory in Criminology: The Path Not Taken. The Jjournal of Criminal Law and Criminology.

Macfarlan, A. L. M. (n.d). Better Evaluation. Retrieved n.d. 28th May 2019, n.d., from -: https://www.betterevaluation.org/en/plan/approach/success-case-method

Arvinder P. S., Loomba, R. K. (2019). Self-efficacy's role in success of quality training programmes. Industrial and Commercial Training, 24-39.

Arvinder, P. S., Loomba, R. K. (2019). Self-efficacy's role in success of quality training programmes. Industrial and Commercial Training, Vol. 51 Issue: 1, 24-39.

Shuaib, A. I. S. (2015). Mstar. Retrieved from https://www.mstar.com.my/lokal/semasa/2015/03/18/sejarah-penjara-malaysia

Azizah, H. (2010). Kaedah Kualitatif dalam Penyelidikan Sosiobudaya. Pengajian Media Malaysia.

Azman, N. (2009). Panduan Amalan Pengajaran dan Pembelajaran Berkesan . Bangi: PPA, UKM,.

Babbie, E. (2010). The Practice of Social Research. United States of America: Wadsworth Cengage Learning.

Bachtiar, H., Mattulada, W., \& Soebadio, H. (1985). Budaya dan Manusia Indoneisa. Yogyakarta: Hanindita.

Bahagian Pengurusan Banduan, Jabatan Penjara Malaysia. (2014). Pamplet Program Pembangunan Insan. Kajang, Selangor: Bahagian Pengurusan Banduan, Jabatan Penjara Malaysia.

Baxter, L., Hughes, C., \& Tight, M. (2006). How to Research. Maidenhead Berkshire: Open University Press.

BBC News. (2017). BBC News. Retrieved from https://www.bbc.com/news/world-latinamerica-38534769

Berita Harian. (2020). Berita Harian. Retrieved from https://www.bharian.com.my/berita/nasional/2020/03/665949/covid-19-kerajaanumum-perintah-kawalan-pergerakan-mulai-rabu

Boris Groysberg, J. L.-J. (2018). The Leaders' Guide To Corporate Culture. How To Manage The Eight Critical Elements Of Organizational Life, 4.

Brown, D. R. (2011). Experiential Approach to Organization Developmen. New Jersey: Pearson.

Campbell, L. (2017). Huffpost. Retrieved November 27, 2018, from https://www.huffingtonpost.com.au/2017/10/18/weve-broken-down-your-entirelife-into-years-spent-doing-tasks_a_23248153/

Career Research. (2020). Career Research. Retrieved from http://career.iresearchnet.com/career-development/social-cognitive-career-theory/

Gisler, C. I. P. (2018). Experiences with Welfare, Rehabilitation and Reintegration of Prisoners. Geneva: United Nations Research Institute for Social Development (UNRISD).

Nasir, C. M. N., Ahmad, N. A., Abdul Hamid, A. S., Abdul Ghani, M., \& Jasni, M. A. (2020). Faktor risiko dinamik residivisme dalam kalangan Orang DiParol (ODP): Perspektif kakitangan Parol. EDUCATUM - Journal of Social Science (EJOSS), Vol.6 No.1, 22-32.

Che Noh, N. (2020). Harian Metro. Retrieved from 
https://www.hmetro.com.my/mutakhir/2020/02/544312/beri-peluang-banduanbina-Irt3

Clark, P. (1975). Organisation Behaviour. Industrial and Commercial Training, pp. 188-193.

Coyle, A., \& Fair, H. (2018). Handbook for Prison Staff. London: Institute for Criminal Policy Research Birkbeck, University of London.

Pugh, D. J. (Jun, 1968). Dimensions of Organization Structure. Administrative Science Quarterly, Vol. 13, No. 1 , pp. 65-105.

Dawson, C. (2002). Practical Research Methods. United Kingdom: How to Books.

Denzin, N. (1978). The Research Act: A Theoritical Introduction in Sociological Methods. New York: McGraw-Hills.

Dewan Bahasa dan Pustaka. (2005). Kamus Dewan. Kuala Lumpur: Dewan Bahasa dan Pustaka.

Downes, A. (2019). https://www.watershedlrs.com. Retrieved n.d. 28th May 2019, n.d., from https://www.watershedlrs.com/blog/anderson-learning-evaluation: https://www.watershedlrs.com/hubfs/CO/Anderson_White_Paper/Learning_Evaluat ion_Anderson.pdf

Downes, A. (2019). WatershedLRS.com. Retrieved n.d. 28th May 2019, n.d., from -: https://www.watershedlrs.com/hubfs/DOCUMENTS/Learning_Evaluation_Brinkerho ff_.pdf

Downes, A. (n.d). WatershedLRS.com. Retrieved n.d. 28th May 2019, n.d., from https://www.hubspot.com: https://cdn2.hubspot.net/hubfs/742406/CO/KaufmaneGuide/Learning_Evaluation_Kaufman_.pdf

Drani, S., Azman, A., \& Singh, J. P. S. (2019). Pengetahuan Gelandangan Terhadap Peranan dan Keperluan Pekerja Sosial. Malaysian Journal of Society and Space 15 Issue 2, 141154.

Edward, E. S. (1963). Reviewed Work: Formal Organization: A Comparative Approach by Peter M. Blau, W. Richard Scott. The University of Chicago Press Journals, 237-240.

Evaluation Resource Center for Advanced Technological Education. (2012). Kirkpatrick Model for ATE Evaluation. EvaluATE. Kalamazoo, Michigan, United States of America: West Michigan University.

Fraenkel, J. R., \& Wallen, N. E. (2012). How To Design and Evaluate Research in Education. New York: McGraw-Hill.

Gary, N., McLean, M.-H. (2006). Social Development through Human Resource Development. United Nation's Millennium Development Goals.

Gary Parkinson, A. R. (n.d.). Online Dictionary of Social Sciences. Retrieved from Online Dictionary of Social Sciences: http://bitbucket.icaap.org/dict.pl

Gray, D. (2004). Doing Research in the Real World. London: SAGE Publications.

Greenwald, H. P. (2008). http://dx.doi.org/10.4135/9781483329635.

Gross, E. (1969). The Definition of Organizational Goals. The British Journal of Sociology.

Gunawan, V. P., \& Yuliati, R. (2019). APLIKASI MODEL SOCIAL COGNITIVE CAREER THEORY UNTUK MEMPREDIKSI NIAT MAHASISWA BEKERJA SEBAGAI AKUNTAN PUBLIK. Jurnal Ekonomi, Keuangan, Perbankan dan Akuntansi Vol. 11, No. 1, 35 - 54.

Hadi, M., \& Azlinda, W. M. (2015). Reducing Recidivism Rates through Vocational Education and Training. 4th World Congress on Technical and Vocational Education and Training (WoCTVET) (pp. 272 - 276). Malaysia: Elsevier Ltd.

Harian Metro. (2019). Pressreader.com. Retrieved from https://www.pressreader.com/malaysia/harian-metro/20190505/282316796466305 
Harvey, B. (2010). Non-employee critical HRD:empowerment and communities. Journal of European Industrial Training, 176 - 183.

Hasnizam, H., Norman, Z., Jen-T Chiang, C., \& Rajamanickam, R. (2018). Program Pemulihan di dalam Penjara bagi Pesalah Jenayah: Kajian di Jabatan Penjara Malaysia. JUUM (ISU KHAS/SPECIAL ISSUE), 72-85.

Hassan, M. R. (2020). Temubual Mendalam. (M. R. Mohd Rosli, Interviewer)

Hassan, M. R. (2020). Temubual Mendalam - menerusi aplikasi Whatsapp. (M. R. Mohd Rosli, Interviewer)

Idris, M. A., \& Anuar, R. M. (2017). GOLONGAN GELANDANGAN DI MALAYSIA: ANTARA PERLUASAN TAFSIRAN ASNAF IBNU AL-SABIL DAN AL-RIQAB. Shah Alam: Akademi Pengajian Islam Kontemporari, Universiti Teknolgi Mara.

Idris, M. D. (2020). Temubual Mendalam Kajian "Progam Latihan Vokasional dan Adaptability Kerjaya Banduan". (M. R. Mohd Rosli, Interviewer)

Institute for Crime and Justice Policy Research. (2020, May 31). World Prison Brief. Retrieved from https://www.prisonstudies.org/country/malaysia

Ishak, K., Dawi Cahyono, I. M., Wahid, H., \& Ahmad, S. (2016). Cadangan Bantuan Zakat Asnaf Al-Riqab Terhadap Banduan Melalui Latihan Vokasional Di Penjara: Kajian Di Penjara Wanita Kajang, Selangor. Jurnal Pengurusan dan Penyelidikan Fatwa Vol. 7.

Jabatan Audit Negara Malaysia. (2013). Laporan Ketua Audit Negara. Putrajaya: Jabatan Audit Negara Malaysia.

Jabatan Pembangunan Kemahiran. (2017). Jabatan Pembangunan Kemahiran. Retrieved from https://www.dsd.gov.my/jpkv4/index.php/my/perkhidmatan/skm

Jabatan Penjara Malaysia. (2000). PERATURAN-PERATURAN PENJARA 2000. AKTA PENJARA 1995. Malaysia.

Jabatan Penjara Malaysia. (2012). Portal Rasmi Jabatan Penjara Malaysia. Retrieved from Profil Bahagian Pengurusan Banduan:

http://www.prison.gov.my/portal/page/portal/hijau

Jabatan Penjara Malaysia. (2020). JPM Portal. Retrieved from http://jpmportal.prison.gov.my/parol/index.php/sejarah-parol

Jabatan Penjara Malaysia. (2020). Portal Rasmi Jabatan Penjara Malaysia. Retrieved from http://www.prison.gov.my/portal/page/portal/hijau/berita?fac_next_page=htdocs/ berita/ViewBerita.jsp?id=8164

Jabatan Penjara Malaysia. (2020). Portal Rasmi Kementerian Dalam Negeri. Retrieved from http://www.moha.gov.my/images/terkini/FAQ_KDN_21_MAC_2020_update_21_Ma c_20204pm.pdf

Jacobs, R. L. (2006). PERSPECTIVES ON ADULT EDUCATION, HUMAN RESOURCE DEVELOPMENT, AND THE EMERGENCE OF WORKFORCE DEVELOPMENT. NeW Horizons in Adult Education and Human Resource Development, 21-31.

Jacobson, J., Head, C., \& Fair, H. (2017). Prison: Evidence of its use and over-use from around the world. London: Institute for Criminal Policy Research (ICPR).

Jasmi, K. (2012). Metodologi Pengumpulan Data dalam Penyelidikan Kualitatitif. Kursus Penyelidikan Kualitatif Siri 12012 (pp. 1-26). Johor Bahru: Institut Pendidikan Guru Malaysia Kampus Temenggong Ibrahim.

Jasni, M. A., Abu Bakar Ah, S. H., Yusoff, M. J. Z., Shahid, M. K., Omar, N., \& Azman, Z. (2018). Kekurangan Akses kepada Jagaan Lanjutan dan Faktor-Faktor Risiko Yang Membawa Kepada Relaps Dadah dalam Kalangan Bekas Banduan. Jurnal Perspektif Jil. 10 Bil. 2 , 34-44. 
Jasni, M. A., Abu Bakar Ah, S. H., Yusoff, M. J. Z., Shahid, M. K., Omar, N., \& Azman, Z. (2019). Fungsi Rumah Perantaraan sebagai Penempatan Sementara untuk Bekas Banduan di Malaysia. Akademika 89(2), 17-31.

Jasni, M. A., Abu Bakar Ah, S. H., Yusoff, M. J. Z., Shahid, M. K., Omar, N., \& Azman, Z. (2018). Faktor penghijrahan dan penumpuan bekas banduan di Jalan Chow Kit, . Malaysian Journal of Society and Space 14 issue, 87-101.

Jon, M., Werner, R. L. (2012). Human Resource Development, Sixth Edition. South-Western Publishing Co.

Kamsani, N. (2017, Ogos 20). Astro Awani. Retrieved from http://www.astroawani.com/gayahidup/tak-sangka-kain-tenun-saya-reka-jadi-pilihan-tunku-tun-aminah-tengku-puanpahang-152955

Kasilingam, G., Ramalingam, M., \& Chinnavan, E. (2014). Assessment of learning domains to improve student's learning in higher education. Journal of Young Pharmacists Vol. 6, Issue 4.

Kementerian Dalam Negeri. (2000). PERATURAN-PERATURAN PENJARA 2000. Malaysia: Kementerian Dalam Negeri.

Kementerian Dalam Negeri. (2018). Portal Data Terbuka Malaysia. Retrieved from http://www.data.gov.my/data/ms_MY/dataset/senarai-institusi-jabatan-penjaramalaysia

Kim, N. (2012). Societal Development Through Human Resource Development: Contexts and Key Change Agents. Advances in Developing Human Resources, pp. 239-250.

Kothari, C. (2004). Research Methodology Methods and Techniques. New Delhi: New Age international (P) Ltd., Publishers.

Gay, G. E. (2012). Educational Research Competencies for Analysis and Applications. New Jersey: Pearson Education, Inc.

Lebar, O. (2018). Penyelidikan Kualitatif: Pengenalan Kepada Teori dan Metode. Tanjong Malim: Universiti Pendidikan Sultan Idris.

Lunenberg, F. C. (2012). Organizational Structure: Mintzberg's Framework. International Journal of Scholarly, Academic Intellectual Diversity, Volume 14, Number 1.

MalayMail. (2019). malaymail.com. Retrieved from https://www.malaymail.com/news/malaysia/2019/06/12/selangor-kuala-lumpurprisons-overcrowded-by-3700-inmates-says-prisons-dire/1761546

Malaysian Administrative Modernisation and Management Planning Unit (MAMPU). (2018). Official Portal MAMPU. Retrieved November 27, 2018, from Official Portal MAMPU: http://www.mampu.gov.my/en/

Malcolm S. Knowles, R. A. (2005). The Adult Learner, Sixth Edition_ The Definitive Classic in Adult Education and Human Resource Development. Butterworth-Heinemann.

Mansfield, R. (n.d.). Organisational Environments and Organisational Design.

Marican, S. (2005). Kaedah Penyelidikan Sains Sosial. Petaling Jaya: Pearson Prentice Hall.

Masri, R., Ahmad, A., \& Abd Rani, R. (2018). Teori Maslow Dalam Konteks memenuhi Keperluan Asas Pekerja dan Peranannya Dalam Meningkatkan Prestasi Organisasi: Kajian dan Persepektif Islam. Jurnal Hadhari, Vol.10, No.1.

Ruzki, M. R., Idris, R., Iskandar, I. M., Parzi, M. N., Ibrahim, F. M., \& Muzamir, M. Y. (2020). Berita Harian. Retrieved from https://www.bharian.com.my/berita/nasional/2020/05/683811/perintah-kawalanpergerakan-bersyarat-mulai-4-mei

Matsueda, R. L. (1988). The Current State of Differential Association Theory. SAGE Journals. 
May, M. E. (2007). The Elegant Solution . London: Simon \& Schuster.

Mazhar, H. B., Wormith, S. J., \& Zidenberg, A. M. (2018). Assessing the Relationship Between Religiosity and Recidivism Among Adult Probationers in Pakistan. International Journal of, 1-29.

McNally, J. (2018). The Functions of the Executives. Academy of Management Learning and Education, 112-114.

Mohamad, M. B. (2012). Doktor Umum. Kuala Lumpur: MPH Group Publishing Sdn Bhd.

Mohammed, H., \& Mohamed, W. A. (2014). Reducing Recidivism Rates through Vocational Education and Training. 4th World Congress on Technical and Vocational Education and Training (WoCTVET), 5th-6th. Elsevier Ltd.

Daud, M. A. J. A. (2016). Meninjau kembali Dasar Pandang ke Timur Mahathir: Penelitian aspek perlaksanaan dan implikasi. GEOGRAFIA OnlineTM Malaysian Journal of Society and Space, 79-91.

Alif, M. J., Hajar, S. A. B., Jal Zabdi, M. Y., Khairiyah, M. S., \& Noralina, O. (2017). Konsep Residivisme: Kekaburan Definisi, Pengukuran dan Praktis. Akademika, 101-122.

Moleong, L. (1989). Metodologi Penelitian Kualitatif. Bandung: Remaja Rosdakarya.

Mynewshub. (2015). Mynewshub. Retrieved from https://www.mynewshub.tv/terkini/program-pemulihan-banduan-berjayakurangkan-kes-berulang/

MyPride. (n.d.). MyPride. Retrieved from http://tempahan.prison.gov.my/tempahan/

Nambiar, S. (2009). REVISITING PRIVATISATION IN MALAYSIA:THE IMPORTANCE OF INSTITUTIONAL PROCESS. Asian Academy of Management Journal, 21-40.

Muhammad, N. M. N. F. M. (2011). Mydin transformation focus: leadership nd organizatonal change. Emerald Emerging Markets Case Stuiesj, 1-16.

O'Hara, S. W. (1996). Action learning in management education, Vol.38 Iss 8. Education + Training, $16-21$.

Omar, Z. (2000). CURRENT ISSUES IN CORRECTIONAL TREATMENT AND EFFECTIVE COUNTERMEASURES. 115TH INTERNATIONAL TRAINING COURSE (pp. 333-351). Tokyo: United Nations Asia and Far East Institute for the Prevention of Crime and the Treatment of Offenders (UNAFEI) .

Orang Perak. (2019). orangperak.com. Retrieved fromhttps://www.orangperak.com/penjarataiping-kompleks-penjara-pertama-di-malaysia.html

Parlimen Malaysia. (2019). Pemberitahuan Pertanyaan Jawab Lisan Dewan Rakyat. Kuala Lumpur: Parlimen Malaysia.

Parlimen Malaysia. (2019). Pemberitahuan Pertanyaan Lisan Dewan Rakyat. Kuala Lumpur: Parlimen Malaysia.

Parlimen Malaysia. (2017). Pemberitahuan Pertanyaan Bagi Jawapan Bukan Lisan Mesyuarat Kedua, Dewan Rakyat. Kuala Lumpur: Parlimen Malaysia.

Parlimen Malaysia. (2019). Pemberitahuan Pertanyaan Lisan Dewan Rakyat. Kuala Lumpur: Parlimen Malaysia.

Patton, M. (1990). Qualitative Evaluation and Research Methods 2nd edn. California: Sage Publicatioons.

Perak Today. (2016). Perak Today. Retrieved from https://peraktoday.com.my/2016/01/jabatan-penjara-naik-taraf-portal-mypride/

Pesuruhjaya Penyemak Undang-Undang Malaysia. (2008). Akta Penjara 1995. Akta Penjara 1995. Malaysia. 
Rashidi, R. H. (2006). Framework for Effective Collaboration between Public Training Institutions and Industries in the Context of the National.

Rosli, F. A. (2019). Berita Harian. Retrieved from https://www.bharian.com.my/rencana/komentar/2019/06/572561/peluang-keduaelak-bekas-banduan-tersisih

Mohamed, R. A. A. (2012). Evaluating the Effectiveness of a Training Program Using the Four Level Kirkpatrick Model in the Banking Sector in Malaysia. 3rd International Conference on Business and Economic Research (pp. -). Bandung: Open University Malaysia.

Saad, J. (2015). Cabaran Dalam Usaha Membangunkan dan Melaksanakan Modul Pemulihan Di Dalam Penjara Untuk Pesalah Jenayah Syariah. Kanun: Jurnal Undang-Undang Malaysia Vol. 27, No.1, 169-178.

Samad, I., Mustafa, J., \& Ab Hamid, K. (2017). Faktor-Faktor Mempengaruhi Residivisme Banduan di Penjara Taiping. Malaysia Correctional Journal, 57.

Samsudin, M. (2017). Sejarah Penubuhan Sistem Penjara Malaysia di Pulau Pinang. Malaysia Correctional Journal, 30.

Savickas, M. L., \& Porfeli, E. J. (2012). Career Adapt-Abilities Scale: Construction, reliability, and measurement equivalence across 13 countries. Journal of Vocational Behavior, 661-673.

Sham, S., \& Selvaratnam, D. P. (2018). Strategi Kelangsungan Hidup Gelandangan di Pusat Bandaraya Kuala Lumpur. Sains Humanika.

Shamsuddin, M. A. (2019). Berita Harian. Retrieved from https://www.bharian.com.my/berita/wilayah/2019/07/586399/rm41-sehari-kosmakan-minum-banduan

Harian, S. (2019). Sinar Harian. Retrieved from https://www.sinarharian.com.my/article/36515/SIASAT/Hasil-tangan-banduanjimat-kos

Harian, S. (2019). Sinar Harian. Retrieved from https://www.sinarharian.com.my/article/37694/BERITA/Nasional/Permaisuri-Agongluang-masa-bersama-banduan-Penjara-Penor

Singh, Y. K. (2006). Fundamental of Research Methodology and Statistics. New Delhi: New Age International (P) Limited Publishers.

Sitorus, M. (1998). Penelitian Kualitatif: Suatu Perkenalan. Bogor: Dokis.

Star Media Group Berhad. (2019). MStar. Retrieved from https://www.mstar.com.my/lokal/semasa/2019/11/30/memperkasa-tvet

Taylor, S. J. R. B. (1984). Introduction to Qualitative Research Methods: The Search for Meanings. Toronto: John Wiley and Sons.

Tharshini, N. K., Ibrahim, F., Mohamad, M. S., \& Zakaria, E. (2018). Challenges in Re-Entry among Former Inmates: A Review. International Journal of Academic Research in Business and Social Sciences, 970-979.

The Sundaily. (2018). TheSundaily. Retrieved from https://www.thesundaily.my/archive/overcrowding-more-50-prisons-malaysiaJUARCH579063

Thomas, G., Reio, J. (2007). EXPLORING THE LINKS BETWEEN ADULT EDUCATION AND HUMAN RESOURCE DEVELOPMENT: LEARNING, RISK-TAKING, AND DEMOCRATIC DISCOURSE. New Horizons in Adult Education and Human Resource Development, 5-12. 
UNAFEl. (2008). Promoting Public Safety and Controlling Recidivism using Effective Interventions with Offenders whilst Serving their Sentences: an Examination of best Practices. 135th international senior seminar. Tokyo: United Nations Asia and Far East Institute for the Prevention of Crime and the Treatment of Offenders (UNAFEI).

UNODC, U. N. (2013). Handbook on Strategies to Reduce Overcrowding in Prisons. New York: United Nations Office on Drugs and Crime (UNODC).

UNODC, United Nations Office on Drugs and Crime. (October 2017). Roadmap for the Development of Prison-based Rehabilitation Programmes. Vienna: United Nations Office.

Walliman, N. (2011). Research Methods: The Basics. New York: Routledge.

Walmsley, R. (2018). World Prison Population List. London: Institute for Criminal Policy Research.

Wiatrowski, M. D., Griswold, D. B., \& and Roberts, M. K. (1981). Social Control Theory and Delinquency. American Sociological Review, 525-541.

Wolters, O. (1979). Studying Srivijaya. Journal of Malaysian Branch of the Royal Asiatic Society, 1-52.

World Health Organization (WHO) Global Service Center, Malaysia. (2018). Defining Corporate Values Briefing Pack. Cyberjaya: WHO GSC Malaysia.

Wright, T., \& Frigerio, G. (2015). The Career Adapt-ability Pilots Project. York: The Higher Education Academy.

Yaacob, H. (2012). Cost Benefit Analysis: Transforming Malaysian Prison Department Towards Income Generating Through Islamic Finance Products. Persidangan Kebangsaan Ekonomi Malaysia ke VII (PERKEM VII) (pp. 1494 - 1501). Ipoh: PROSIDING PERKEM VII, JILID 2.

Hamin, Z. M. B. (2017). Predicaments in Prisoners' Institutional Rehabilitation for Parole Release: Some Evidence from Malaysia. The Howard Journal of Crime and Justice Vol 00 No 0. $x x x x, 1-17$.

Zimring, F. E. (2010). The Scale of Imprisonment in the United States: Twentieth Century Patterns and Twenty-First Century Prospects. Journal of Criminal Law and Criminology, 1230.

Zulkifli, O. (2000). Current Issues in Correctional Treatment and Effective Countermeasures. United Nations Asia and Far East Institute for the Prevention of Crime and the Treatment of Offenders (UNAFEI) 115th International Training Course (pp. 333-351). Vienna: United Nations Asia and Far East Institute for the Prevention of Crime and the Treatment of Offenders (UNAFEI).

Zulkifli, O. (2017). Perutusan Tahun Baru 2018. Jabatan Penjara Malaysia, Kajang.

Zulkifli, O. (2019). Ucapan Sambutan Hari Penjara Ke-229. MAKTAB PENJARA MALAYSIA, Kajang, Malaysia. 